\title{
Emerging contaminants in consumer products: environmental fate and transfer to human food-chain
}

\author{
T. Eggen ${ }^{1}$, M. Möder ${ }^{2}$ \& A. Arukwe ${ }^{3}$ \\ ${ }^{1}$ Bioforsk Vest Scerheim, Norway \\ ${ }^{2}$ Department of Analytical Chemistry, \\ Helmholtz Centre for Environmental Research, Leipzig, Germany \\ ${ }^{3}$ Department of Biology, \\ Norwegian University of Science and Technology (NTNU), Norway
}

\begin{abstract}
A wide range of compounds originating from everyday products with beneficial qualities for humans are transferred to the environment and potentially to the animal- and human food-chain. Many of these compounds are emerging contaminants that are perceived or with real human and environment health hazard.

Herein, we have evaluated the sources and fate of selected emerging organic contaminants in human food items. In addition, we also investigated the distribution patterns in water- and particle phases, calculated concentration level in human food items based on bioaccumulation factors for fish and plant species, together with reported or estimated environmental concentrations for these emerging contaminants. Overall, given the general knowledge gap on risk assessment and food safety concerns for these emerging contaminants, the present study provides significant insights and information for evaluating the potential health hazards of these chemicals.

Keywords: emerging contaminants, legacy contaminants, pharmaceuticals, bioaccumulation factors, plant uptake, food safety, risk assessments.
\end{abstract}




\section{Introduction}

Emerging contaminants are continuously identified in the environment. As a result of their transfer in food-chains, perfluorinated compounds (PFC) used as surface-active substances, veterinary- and human pharmaceuticals, anti-bacterial agents, personal care products such as fragrances, polycyclic musk compounds and organophosphate flame retardants are groups of compounds that have recently gained focus as potential threat to animal- or human health. Additives in consumer product are a major source of these compounds. These additives are introduced to the products due to their excellent properties that improve product quality including - repelling water and oil, good smell, preventing bacterial growth and fire. Pharmaceuticals are positive substances and are prescribed for specific purposes. However, pharmaceuticals in the environment represent hazard as they might be exposed to non-target organisms, including humans. Product additives and pharmaceuticals might be transferred to the environment either through municipal landfill leachates where additives are released from the product during decomposition over time [1] or domestic and municipal waste water that may contain the same additives due to daily use of cosmetic products, softeners, tooth paste and laundry of textiles coated with flame retardants and anti-bacterial agents.

In the study, we have evaluated the sources and fate of selected emerging organic contaminants in human food items. The concentration level in human food items were calculated based on bioaccumulation factors for fish and plant species and reported or estimated environmental concentrations for these emerging contaminants.

\section{Methodology part}

Selection of emerging compounds of interest was performed based on reported or predicted presence in relevant environmental matrixes and potential transfer and exposure to aquatic or terrestrial food items. Important properties for evaluating the environmental fate organic compounds include - water solubility, affinity to water and hydrophobic phases presented by octanol-partition coefficient $(\log \mathrm{P}$ or $\log \mathrm{D})$, distribution coefficient between soil and water $\left(\mathrm{K}_{\mathrm{d}}\right)$, distribution coefficient between water and air (Henrys law constant). In this study, we have included compounds that cover a wide range of properties. In order to predict the fate of emerging organic contaminants during a treatment process, several of our selected compounds of interest were analyzed both in water- and particle phase of samples from a municipal landfill leachates and influent to waste water treatment plant (WWTP [2]).

Transfer to aquatic environment and exposure to relevant aquatic organisms are based on reported and predicted environmental levels and bioaccumulation factors, while transfer to important crops used for animal forage and human food is based on greenhouse plant uptake experiment. Plants were grown in pots spiked with the test compounds, harvested, dried and analyzed as described elsewhere [3]. Residue levels in several food items were estimated based on 
experimental or calculated bioaccumulation factors for fish and different plant species, and concentration levels in environmental matrixes such as lake, seawater and agricultural soil. There are different BCFs for fish and an evaluation of their suitability is also presented. Thus, $\mathrm{BCF}_{\text {fish }}$ from Technical Guidance Document (TGD) [4] is used as an example;

For individual compounds:

$\log \mathrm{K}_{\mathrm{ow}} \leq 6: \log \mathrm{BCF}_{\text {fish }}=0.85 \cdot \log \mathrm{K}_{\mathrm{ow}}-0.70$

$\log \mathrm{K}_{\mathrm{ow}}>6: \log \mathrm{BCF}_{\text {fish }}=-0.20 \cdot\left(\log \mathrm{K}_{\mathrm{ow}}\right)^{2}+2.74 \cdot \log \mathrm{K}_{\mathrm{ow}}-4.72$

$\mathrm{BCF}$ is given on wet weight basis $(1 / \mathrm{kg})$. The steady-state concentration in fish is further given by:

$\mathrm{C}_{\text {fish }}=\mathrm{BCF}_{\text {fish }} \cdot$ water, given as $\mathrm{mg} / \mathrm{kg}$ wet fish.

Table 1: Information about the compounds of interest, their application and consumer products where they have been used - or still used as additives.

\begin{tabular}{|c|c|}
\hline Consumer products & $\begin{array}{l}\text { Examples of additives/active } \\
\text { compounds }\end{array}$ \\
\hline $\begin{array}{l}\text { Textiles e.g. sport wears, toothpastes, } \\
\text { hand soaps, deodorants, yoga mats, } \\
\text { kids' toys }\end{array}$ & Anti-bacterial agent Triclosan \\
\hline $\begin{array}{l}\text { Cleaning agents, floor and car polishing } \\
\text { products, rain cloths, treating carpets, } \\
\text { impregnation sprays for textiles }\end{array}$ & $\begin{array}{l}\text { Water and oil repellents, detergent } \\
\text { PFC }\end{array}$ \\
\hline Anti-mosquito & $\begin{array}{c}\text { Insecticide N.N-diethyl toluamide } \\
\text { (DEET) }\end{array}$ \\
\hline $\begin{array}{l}\text { Personal care products e.g. shampoos, } \\
\text { laundry detergents, household surface } \\
\text { cleaners, care products }\end{array}$ & Galaxolide, tonalide \\
\hline $\begin{array}{l}\text { Rigid and flexible polyurethane foam, } \\
\text { thermostat and thermoplastic materials, } \\
\text { in textile finishes }\end{array}$ & $\begin{array}{c}\text { Flame retardants Tris(1-chloro-2- } \\
\text { propyl) phosphate (TCPP) }\end{array}$ \\
\hline Pharmaceuticals & Antibiotic ciprofloxacin \\
\hline
\end{tabular}

Representatives of legacy or emerging organic contaminants of interest included in the present study are shown in Table 1. Environmental concentrations (measured or estimated) and BCF (fish and some plant species) for three of the compounds are shown in Tables 2 and 3, respectively. The 
compounds presented here are the organophosphate flame retardant, Tris(1-chloro-2-propyl) phosphate (TCPP), the musk compound, tonalide and the antibiotic, ciprofloxacin.

Table 2: $\quad$ Concentrations in relevant environmental matrices.

\begin{tabular}{cccc}
\hline Compounds & $\begin{array}{c}\text { Water (river, sea, } \\
\text { lake: } \mu \mathrm{g} / \mathrm{L})\end{array}$ & $\begin{array}{c}\text { WWTP sewage } \\
\text { sludge }(\mathrm{mg} / \mathrm{kg} \mathrm{dw})\end{array}$ & $\begin{array}{c}\text { Agricultural soil } \\
(\mathrm{mg} / \mathrm{kg} \mathrm{dw})\end{array}$ \\
\hline TCPP & $0.005-0.2[5]$ & $1.9[6]$ & $0.0475[4]$ \\
Tonalide & $2.8[7] ; 5.8[8]$ & $3.6[9]$ & $1.02[4]$ \\
Ciprofloxacin & $0.02[10]$ & $10[11] ; 40.8[12]$ & $0.75[13] ; 1.7[14]$ \\
\hline
\end{tabular}

Table 3: $\quad \log \mathrm{K}_{\mathrm{ow}}$ and bioaccumulation factors (BCF) for fish (estimated), root vegetables (experimental) and cereals (experimental) for three selected test compounds.

\begin{tabular}{|c|c|c|c|c|}
\hline \multirow[b]{2}{*}{ Compounds } & \multirow[b]{2}{*}{$\log \mathrm{K}_{\mathrm{ow}}$} & \multicolumn{3}{|c|}{$\mathrm{BCF}$} \\
\hline & & $\begin{array}{c}\text { Aquatic } \\
\text { organisms }\end{array}$ & Carrot root & Barley cereal \\
\hline ТCPP* & 2.59 & 32 & 14.17 & 0.077 \\
\hline Tonalide & 5.7 & 13964 & 0.54 & $<\mathrm{LOD}$ \\
\hline Ciprofloxacin* & 0.28 & 0.345 & 0.06 & 0.00 \\
\hline
\end{tabular}

"Data for TCPP- and ciprofloxacin uptake in plants under publication [3], [15].

Table 4: $\quad$ Predicted concentrations in food items, presented as $\mu \mathrm{g} / \mathrm{kg}$ fresh weight, based on environmental concentration levels given in Table 2 and BCF in Table 3.

\begin{tabular}{cccc}
\hline Compounds & Fish & Carrot root & Barley cereal \\
\hline TCPP & 0.00635 & 201.9 & 3.29 \\
Tonalide & 80989 & 44.36 & $<$ LOD \\
Ciprofloxacin & $6.9 \mathrm{E}-06$ & 18.08 & $<$ LOD \\
\hline
\end{tabular}

LOD: Limit of detection

\section{Conclusion}

- Consumer products are major sources for emerging contaminants. Many of these compounds are detected in the environment, demonstrating potential transfer to human food items. 
- For the three compounds (log $\mathrm{K}_{\mathrm{ow}}$ range 0.28-5.7), the organophosphate flame retardant TCPP $\left(\log \mathrm{K}_{\mathrm{ow}} 2.59\right)$ showed highest BCF in carrot root and barley cereal. High variation between different plant species was observed.

- In the $\mathrm{BCF}_{\text {fish }}$ equation from $\mathrm{TGD}, \log \mathrm{K}_{\mathrm{ow}}$ is the only input parameter. Among the three test compounds, tonalide (log $\mathrm{K}_{\mathrm{ow}}$ 5.7) has highest $\mathrm{BCF}$.

- The database for reliable risk assessment concerning food safety is small and needs to be extended by experimental data.

- In order to estimate residue concentrations in food items, data for environmental concentration levels are needed.

- A "from the cradle to the grave" approach for legacy and emerging contaminants is an effective method for identify compounds with especially high potential for transfer to animal forage and human food items.

- A "from the cradle to the grave" approach is also valuable for identifying the lack of knowledge needed for performing food safety risk assessments.

\section{References}

[1] Slack, R.J., Gronow, J.R. \& Voulvoulis, N., Household hazardous waste in municipal landfills: contaminants in leachate. Science of Total Environment, 337, pp. 119-37, 2005.

[2] Eggen, T, Möder, M. \& Arukwe, A., Emerging Organic Compounds: Sources and Fate Through a Wastewater Treatment Plant and Landfill leachates. Submitted.

[3] Eggen, T., Heimstad, E., Stuanes, A.O. \& Norli, H.-R., Uptake and translocation of emerging organic pollutants in edible plants and the implications for food safety. Submitted.

[4] Technical Guidance Document on Risk Assessment In: European Chemicals Bureau I, ed.: TGD. 2003.

[5] Andresen, J.A., Grundmann, A. \& Bester, K., Organophosphorus flame retardants and plasticisers in surface waters. Science of Total Environment, 32, pp. 155-166, 2004.

[6] Marklund, A., Andersson, B. \& Haglund, P., Organophosphorus flame retardants and plasticizers in Swedish Sewage Treatment Plants. Environmental Science \& Technology, 39, pp. 7423-7429, 2005.

[7] Lee, I.-S., Lee, S.-H. \& Oh, J.-E., Occurrence and fate of synthetic musk compounds in water environment. Water Research, 44, pp. 214-222, 2010.

[8] Heberer, T., Occurrence, fate and assessment of polycyclic musk residues in the aquatic environment of urban areas - a review. Acta Hydrochimica et Hydrobiologica, 30, pp. 227-243, 2002.

[9] Mogensen, B.B., Pritzl, G., Rastogi, S., Glesne, O., Hedlund, B., Hirvi, J.-P., Lundgren, A. \& Sigurdsson, A. Musk compounds in the Nordic environment: TemaNord Report no. 503, 2004.

[10] Kolpin, D.W., Furlong, E.T., Meyer, M.T., Thurman, E.M., Zaugg, S.D., Barber, L.B. \& Buxton, H.T., Pharmaceuticals, hormones, and other 
organic wastewater contaminants in U.S. streams, 1999-2000: a national reconnaissance. Environmental Science Technology, 36, pp. 1202-1211, 2002.

[11] McClellan, K. \& Halden, R.U., Pharmaceuticals and personal care products in archived U.S. biosolids from the 2001 EPA national sewage sludge survey. Water Research, 44, pp. 658-668, 2010.

[12] U.S.EPA report. Targeted national sewage sludge survey. Sampling and analysis technical report. Washington; 2008.

[13] Martínez-Carballo, E., González-Barreiro, C., Scharf, S. \& Gans., O., Environmental monitoring study of selected veterinary antibiotics in animal manure and soils in Austria. Environmental Pollution, 148, pp.570-579, 2007.

[14] Eriksen, G.S., Amundsen, C.E., Bernhoft, A., Eggen, T., Grave, K., Halling-Sørensen, B., Kãllqvist, T., Sogn, T. \& Sverdrup, L., Risk assessment of contaminants in sewage sludge applied on Norwegian soils. Report from The Norwegian Scientific Committee for Food Safety. Oslo, 20 August, 2009.

[15] Eggen, T., Asp, T.N., Grave, K. \& Hormazabal, V., Uptake and translocation of metformin, ciprofloxacin and narasin in forage- and crop plants. Submitted. 